\title{
Expression of the Ordeals of "kayayie" through Mixed-Media Textile Art
}

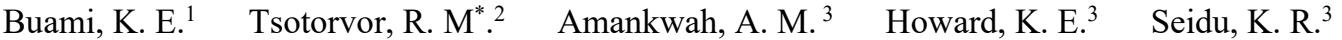 \\ 1 Department of Industrial Art, Faculty of Art and Design, Ho Technical University, Ho, \\ Ghana \\ 2 Akatsi College of Education, private Mail Bag, Akatsi, Ghana \\ 3 Department of Industrial Art, Kwame Nkrumah University of Science and Technology,
} Kumasi-Ghana

\begin{abstract}
The practice of kayayie by young ladies in southern Ghana exposes them to varying difficulties and struggles just to make a living. To bring to the fore such challenges in textile art, the study employed mixed-media materials and techniques to produce art works that communicate their struggles. To achieve the study's focus, the studiobased practice was exercised supported by the Aesthetico-Action Research model by Cora Marshal. Nonparticipant observation and unstructured interview were the main instruments used for data collection. The study revealed three major findings. The first set of findings revealed that, super glue is suitable for varieties of materials and has the ability to wet the fabric to give strong bond with high resistance. Un-primed background before painting resulted in more absorption of paint to fill the amorphous areas of the canvas. Cotton fabric is a suitable substrate for producing mixed media textile art works. The project reveals the possibility of producing textile art using materials available in the environment employing combined techniques like assemblage, painting, sewing and applique to communicate a message. The project recommends that vocational training centres should be built to train kayayie and practicing artists as well as students how to use waste materials in the environment to produce textile art.
\end{abstract}

Keyword: Mixed-media, Textile Art, Kayayie, techniques

DOI: $10.7176 / \mathrm{ADS} / 89-02$

Publication date: January $31^{\text {st }} 2021$

\section{Introduction}

Textile art is the production of art pieces with textiles. Textile artists employs various techniques to execute works of art using materials like threads and fibres sometimes combining it with paints or dye techniques. Some of the techniques employed in textile art include crocheting, embroidery, felt making, applique, lace, needlework, quilting, and sewing, weaving and knotting. Other techniques used are batik, printmaking, marbling, collage, mosaic, fibre art, silk painting are in textile art (Batik Guild, 1999). This evidently shows how one can use different techniques and materials in a single art piece to achieve its results in mixed media provided the selected technique suit the material in use. It also allows the artist a free range of exploration with different media and techniques. Textile artist such as Leisa Rich works in 3D and innovative textile using varied textile materials to create realistic scenes. The project inspiration therefore, was drawn from the $3 \mathrm{D}$ techniques employed by Leisa Rich and served as a guide to execute expression using varied waste materials from the environment.

Mixed media is an alternative means of expression of oneself and creativity where artist produce their ideas and forms in a unique way. It allows immense possibilities and skillful use of wood, metal, yarn, fabric, twine, and other local items in the production of attractive, unique, and functional art piece (Appiah-Ofori, 1991). This term can be applied to all art forms such as metals, ceramics, textiles, painting, sculpture etc. provided it fulfils the requirement above (Adiamah, 1995). Graven (1994) states that mixed media was introduced by the then Dadaists a way to debunk what he refers to as high art, and also, to bring art and real life together. This gives artists different opportunities as opined by Dona (1964) with materials and ideas that can be explored easily by artists either young or old. Mixed media allows the artist to take a fresh look at the most ordinary item and separate them from their everyday environment and uses. On the contrary, Peter and Murray (1983) explain mixed media as an oil painting which include combining different media in a single art piece to create unique effects on a substrate such as canvas, walls and other suitable substrates. These substrates house the varying items as established by Appiah-Ofori but additionally waste materials from the environment can also be employed.

Waste management is imperative to help keep a healthy environment for the well-being of citizens. The advent of industrial revolution has brought different types of waste, each with its own environmental impacts, have come into existence. Waste has been defined as any material or product that has no further use or value for the person or organization and therefore will be discarded. However, what a person may discard as waste may have value to another (Caulfield, 2009). The amount of waste generated, and its actual or potential negative effects on the environment, are matters of concern to governments and communities at large. The use of these 
waste have been employed by varying artist in producing work of art that seeks to expand the materials scope for creativity.

For quite some time now, there has been an increase in the migration of teenage girls and young women who have no education or some limited schooling, into major market centres in southern Ghana. Regarding the influx in the number of female head porters known as kayayie, in the major cities, it is clear that the struggle to curb rural-urban migration is not going to end anytime soon in Ghana despite the numerous promises made by the governments (Mirror, 2017). A woman who takes part in this kind of business is known as a kayayo. Kaya is a Hausa language, which means load or goods. Yo is a Ga language of the people of Accra, which means woman. A kayayo is therefore a teenage girl or young woman who carries people's loads on the head for a charge fee. These teenage girls come principally from the savanna regions of northern Ghana to the southern zone for supposed greener pastures. While in the south these teenage girls engage almost exclusively in the carrying of luggage on their heads for a charge fee. They engage in the head pottering business because they see it as the only self-employment (Mirror, 2017) that could provide them with minimum assets for either marriage or for better standard of living.

Adamson (2007) explains that the skill developed through hand practice in textiles gives the artist command over the production and this involves physical actions. The fabric design pattern serves different purposes, from aesthetic value to function (Terashima, 2009). Seymour (2002) explained that, the process of designing does leads to creative products design. A design could be viewed as an activity that translates an idea into blue print for something useful, whether it is graphical, textiles, ceramics, service or process. The most essential aspect of designing is translation of idea. A design does not have to be new or different in the market to meet its requirement but as long as it is fulfilling a need, it have served its purpose. Design methods also lead to creative products. These can be adapted inventively and by improvisation, in producing textile art forms. The threedimensional pattern with the mixed media techniques is an additive element to the surface that defines a particular appearance (Russell, 2011).

This study seeks to make expressions of kayayie as they carry out their daily business in the street of Kumasi using waste fabric pieces that are picked from the waste bins of dress makers and other waste products from dustbins and landfills. The decision to use waste materials was defined by the essential need to manage and dispose of fabric and other waste product to solve the current issues facing the country such as environmental problems. The idea was developed in a way to put back to use a lot of waste generated in the country that end up in landfills. The culture of upcycling and reusing waste material for textile art is not usual, thus the need to explore and use these materials in producing work of art to widen the scope of artist in Ghana and beyond.

\section{Pioneers of Mixed Media Art}

It gives a free range of material usage and techniques, exploration with different media to set the pace for upcoming artist to experiment further. Appiah (2013) cited El Anatsui and other artists who produced textile art with varied materials for space (see Fig. 1). El Anatsui joined metal pieces to produce fabric that has drape effect. The technique of joining using copper wire is practiced by El Anatsui in his works of art.

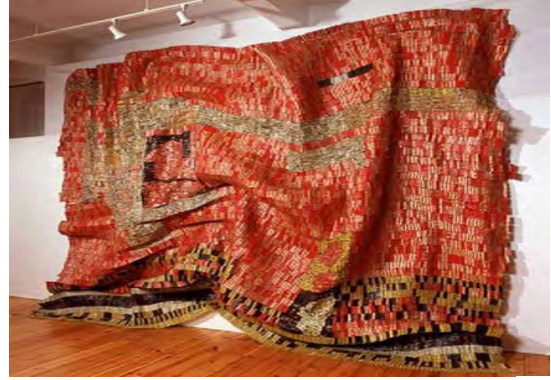

Fig. 1: Joined metal pieces with drapes, 2006

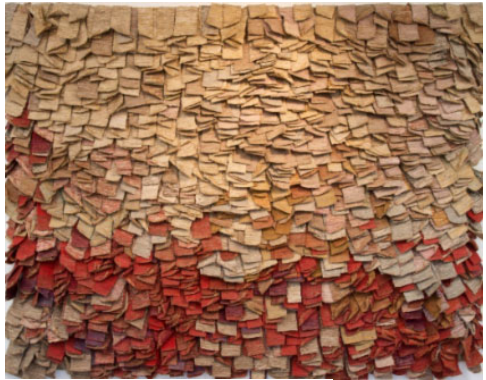

Fig. 2: Paisaje B, 1976 Wool, horsehair

(Source: https://www.artsy.net/)

Olga de Amaral works in three-dimensional art with varied materials such as fibres, metals etc. employing the assemblage technique, these materials are incorporated to produce an art piece (see Fig. 2). Yinka Shonibare uses local prints on dummies. His works focuses on current issues to create awareness. Stitching of African wax prints and assembling such on sculptural figures were the techniques employed in his works (see Fig. 3). 


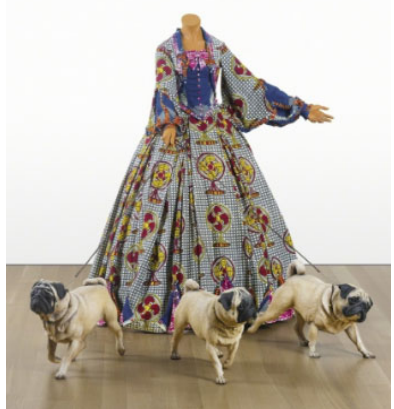

Fig. 3: Leisure Lady (with pugs), 2001

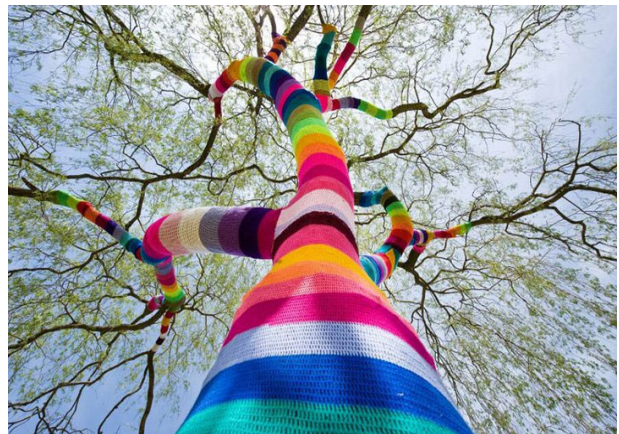

Fig. 4: Crocheted object- Tree, 2008

(Source: https://www.artsy.net/)

Agata Oleksiak covers object with crocheting technique irrespective of the size of the object. Different coloured threads were used in decorating the objects (see Fig. 4). Leisa Rich uses different composite materials to produce works in three dimension and in realism. Different techniques such as painting, stitching and assemblage were key in producing the work of art (see Fig. $5 \mathrm{a}-\mathrm{b}$ ).

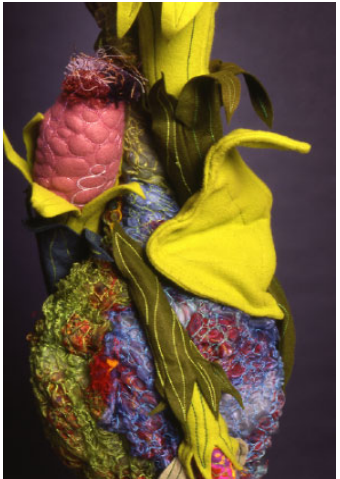

(a)

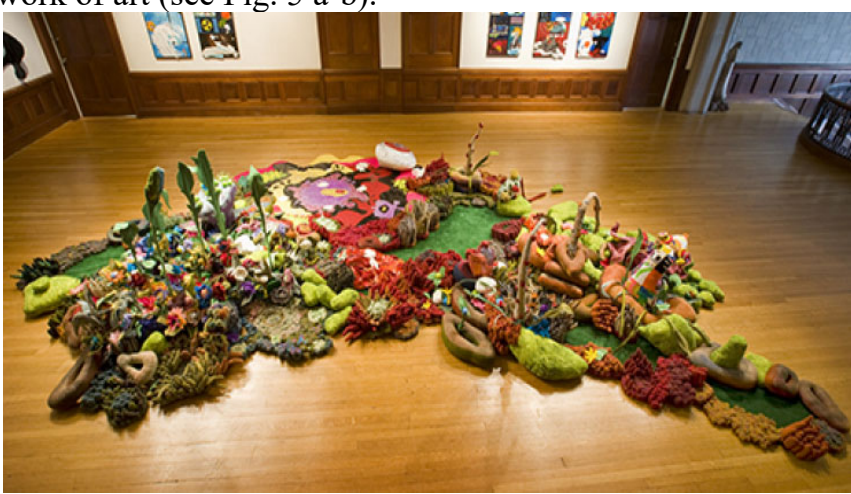

(b)

Fig. 5 (a): Eat Butterflies, 2006, Machine embroidery

Fig. 5 (b): Beauty from the Beast installation, 2009, Mixed Media

(Source: https://www.textileartist.org/leisa-rich-interview-endless-possibilities/)

Gwen Magee also combines cement with fabric material to create a textural surface such as walls and ceilings (see Fig. 6). This really shows that varieties of materials have been employed in a single art piece by artists in the field of textile and this gives the platform for this project to experiment the possibilities of materials using the techniques which encourage the textile art production in Ghana.

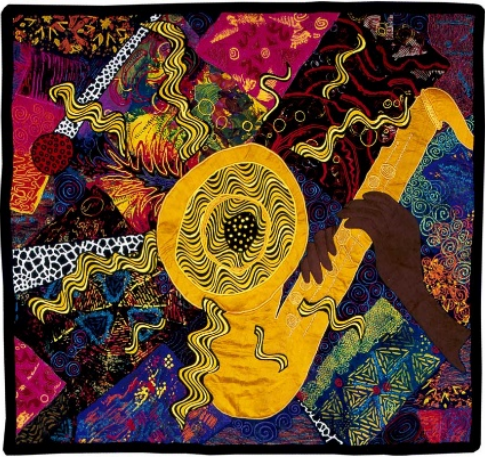

Fig. 5: Jazz-Hot, 2006

(Source: https://folkartmuseum.org/exhibitions/textural-rhythms-constructing-the-jazz-tradition-contemporaryafrican-american-quilts/)

Textile art is the production of works with textile material such as fabric pieces, fibres, yarns and many more which can be combine with various techniques such as crocheting, embroidery, dyeing, knitting, lacing, needlework, appliqueing, quilting, sewing, weaving (interlacing of yarns) and knotting. The above explains clearly the freedom of an artist to explore varieties of technique and materials to produce a unique textile art piece.

Textile Waste Recycling

Aggarwal (2010) explains that recycling means gathering of used items from the environment to produce 
creatively something new. This largely entails the utilization of used items that are possibly useful resources. The two types of textile waste are pre-consumer or post-consumer waste. Therefore as observed by Caulfield (2009) are characterized with discarded materials produce during fabric and garment manufacturing processes. On the other hand, the latter which is the waste from post-consumer textiles comprises the varying forms or style of garments in homes which outlive its functionality and purpose. Barry opines recycling in textiles is the oldest forms of recycling, which commenced in 1813 when Benjamin Law of West Riding area of Yorkshire pioneered the pulling process, where woolen textiles undergo spinning process to produce new threads are they were broken down into their constituent fibres.

The principle exhibited by textile industries on judicious use of materials or resources (Barry, 2000) did not replicate same in their output since a large number of undesirable wastes produced was indiscriminately disposed into the environment. The dynamism in consumer's taste in fashion coupled with designs made for interiors of homes are the influential factor attributed such a situation exhibited by the textile industries. This is to position that such changes in clothing or fashion which occur in seasons largely require rapid change and replacement of designs leading to the disposal of existing ones in the system. This trend permits designers and manufacturers to continually increase the production of clothing in a quest to address such a 'throw-away society' one find oneself in.

\section{Materials and Methods}

The studio-based practice was exercised in the gathering relevant items for producing the textile art forms. Both conventional and non-conventional textile materials were collected as waste from the floor of garment makers and some landfills sites in Ghana. Additionally, other materials like paper card, wood, acrylic paint, high density foam and thin foam, saw dust and shavings, polythene, paper carton and jute among others were employed in the production process. Tools used in executing the art pieces are; cutting tool (scissors), brush, scroll saw piercing machine, carving tool and sharp knife.

In fulfilling the actual production using this methodology, the authors employed the Aesthetico-Action Research Cycle Model by Marshal (2010). The model makes use of four (4) clear reformist steps that certify an activity in the studio comes out effectively as shown in Fig.6.

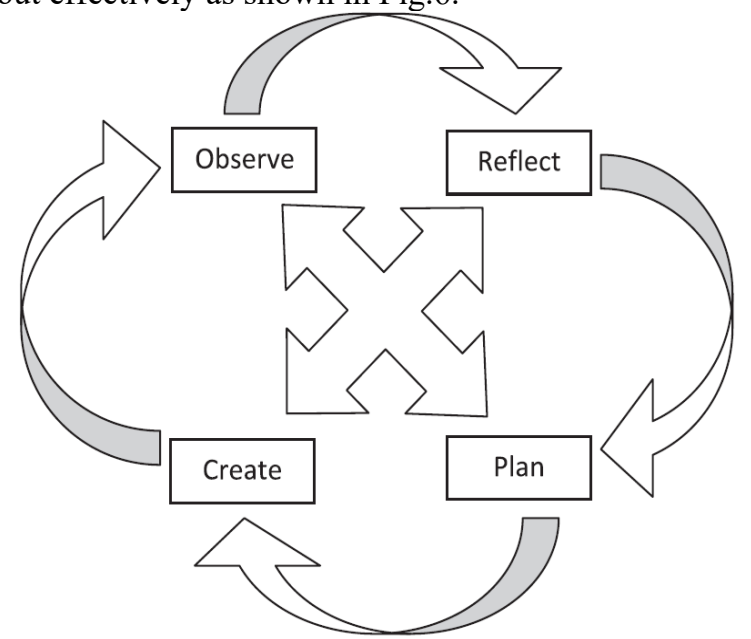

Fig. 6: Aesthetico-Action Research Cycle Source: Cora Marshal (2010)

These steps helped in knowing what is to be done in order to attain the appropriate outcomes. The four steps include: observation, reflection, planning and creating.

Observation: In order to establish a better understanding of 3D textile art on kayayie expression to be worked on, a critical non-participant observation exercise was carried out on kayayie activities in market places in order to ascertain the real issues on the ground to be able to execute the researchers set goals or objectives. Observations were made on 3D art forms of artists like Yinka Shonibare, El-Anatsui, Olga de Amaral, etc. to ascertain the concept of 3D patterns in art in order to aid further reflections. Further observations were made on waste materials and adhesives to ascertain their cohesion bond.

Reflection: The researchers after a full observatory workout, reflected and examined on how the data gathered at the earlier stage, could together be employed into expressive designs. The support or substrate, textile materials and non-textile materials were effectively examined to ascertain their effective utilization in the creation stage. Reflective activities at this stage helped on which patterns could best be put together in a single design to achieve the objectives of producing selected 3D forms on kayayie expression in textile art. 
Planning: This stage ensured that all views made at the reflective stage, are put together into a plan from which expected designs will be created. At this stage the cutting, stitching, pasting, carving and painting of possible patterns to be placed on the support to enhance the actual creation of designs at the final stage were considered.

Creation: This stage involved the actual production where all the suggested ideas from the observatory stage and planning stage are put into real action of practical design to satisfy the importation of objective three. This stage also involved all creative activities which are combined into single art piece ensuring that four (4) different designs on kayayie expression are produced on canvasses.

\section{The 'Kayayie Expression' Concept}

This is derived from Kaya a Hausa word meaning load or goods coupled with a Ga word; Yei denoting females due in part to such role regularly carried out by the latter (Yeboah et al. 2014). Head pottering is an old activity of carrying heavy loads for client for a charged fee, practice by young ladies in Ghana. require the gathering and movement of goods from the farm to a trading centre. The creative process drew inspiration from how some of them struggle with their loads to make an end meet and therefore wants to make expressions of their images as they carry out their daily business. Kayayies carry different materials and products with wooden support, pan and even hand trucks. This has influenced the authors to experiment with different materials in mixed media to bring out the image of Kayayie, looking at their stressful appearance when they are found on the streets. Kayayies have a particular look when you meet them on the streets of Accra and Kumasi busily looking for customers to attend to and make some capital to satisfy their daily needs. After critical observation from the views and ideas derived, it aided in the creative process by developing challenging but interesting designs on fabrics by using gluing, stitching, painting, etc. to serve both functional and aesthetical purposes on the textile art. The literatures provided a great insight on the relevant media and technique employed by artists using mixed-media in producing works of art that seeks to communicate a message to the viewer. This has greatly influenced the project in its conceptual framework which clearly takes inspiration from artists, materials, tools and techniques that ultimately leads to the production of the final product.

\section{Kayayie on their daily routine business on the street of Kumasi}

According to field observation in Kumasi (Central market), kayayie are mostly teenage girls who carries excessive luggage during the busy market days in Kumasi. Their target for the day has set them carrying any form of luggage that may even go a long way to affect their general life. Their carriers are in the form of aluminium bowls, wooden boards and sometimes bear head. Some of them sleeps or seat on or inside their bowl along the street as they wait for a client during the busy market day. The various expression portrayed by these female head potters are enormous. The hazards and strenuous conditions under which they work and abuses they have to undergo before earning a living, it is clear that the impact on their general lives is negative. Some are having babies at their back whilst they carry their luggage which add up to their ordeals. Below are some pictures reflecting their job description on the field in Fig. 7.

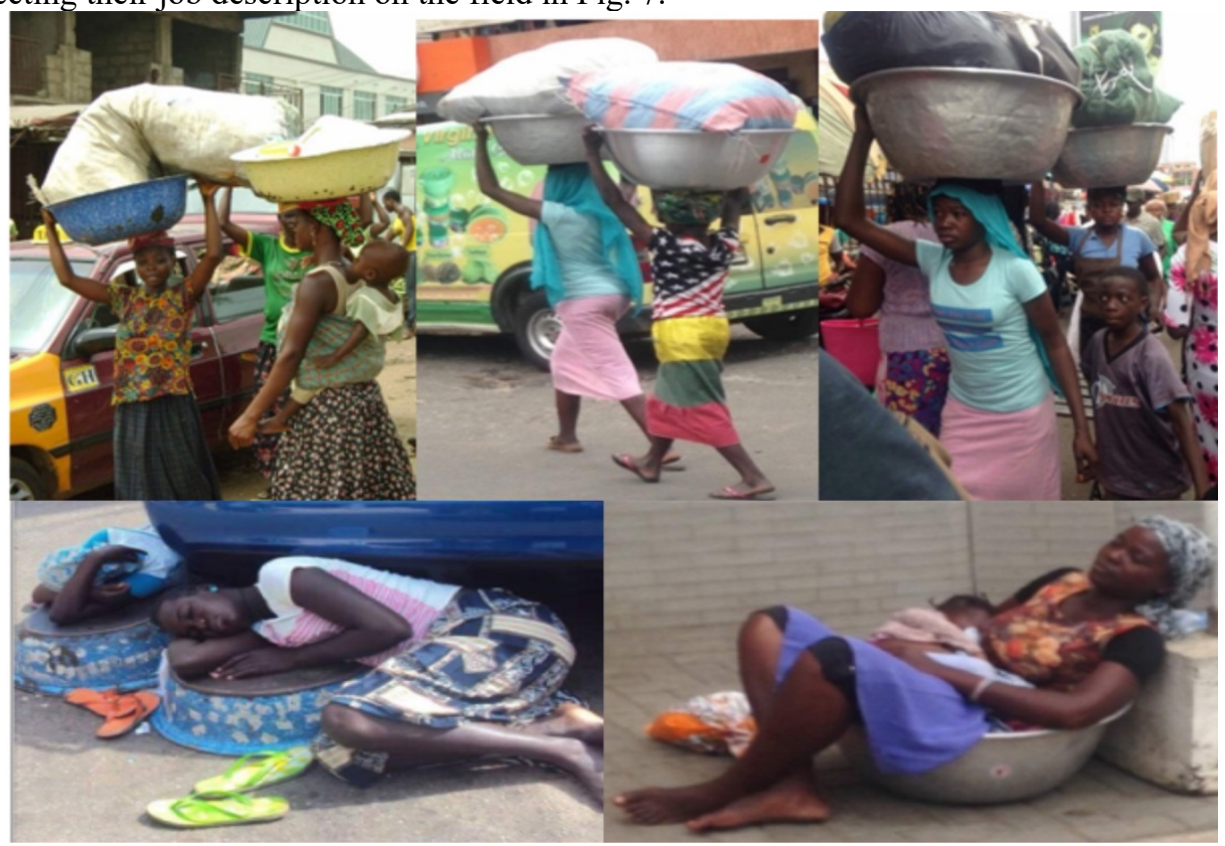

Fig. 7: Sample pictures of kayayie

(Source: Field Survey, 2018) 


\section{Developing Adhesives and Sketch models for the creative process}

The assemblage technique was primarily employed in building up the different items gathered on the surface of the support or substrate (canvas). This phenomenon evidently needed the appropriate adhesive to ensure permanent bonds between the combining items. Essentially, five adhesives (fine glue, fevicol SH, super glue, golden gum, Ecofix 100E) were tested to ascertain their bond effect. It was practically evident that, adhesives like super glue and fevicol SH produced permanent bonds, making it difficult for the items to be detached from the substrate. The other adhesives however produced fragile bonds, a situation which will disintegrate the combining items upon the slightest force. Based on the experimental results, fevicol SH and super glue were exercised in carefully assembling the items on the support.

Sketch models (see Fig. 8) were developed based on inspiration drawn from the images captured from the field observation in Kumasi and Accra.
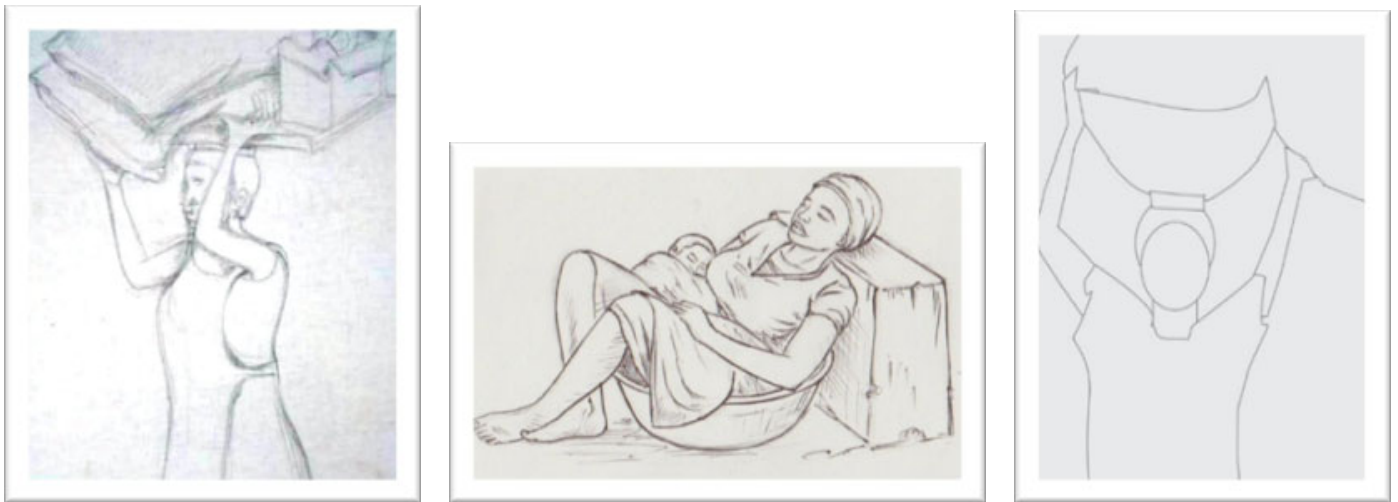

Fig. 8: Sketch models of sample pictures of kayayie

(Source: Studio work, 2019)

These images clearly illustrated the ordeals the young adults (kakayies) go through in their daily activities to make some money for their living. Carrying heavy loads for clients for any length of time is paramount in their practice for a fee. Clear observation from afar would illustrate the weight of the load these ladies carry around for their clients. After such activities, they turn to take a quick rest on some pedestrian walk-way and the stir case of buildings, a situation which sometimes results in confrontations between pedestrians.

\section{Adopted Techniques for the Textile art pieces}

Yarns were unraveled from pieces of fabric and used on the surface of another fabric (calico) by the help of adhesive known as Fevicol SH, a synthetic resin adhesive. The technique (see Fig.9) was built by coiling of yarns in different directions. Yarns were built on each other until a desirable textural effect was achieved. Piece of fabric was cut into a smaller unit and placed randomly on the coiled yarns to add up to the technique. The outcome of the entire technique adopted looks like a bulky item in a sack. The coiled yarns were resisting adhering to the substrate when applied in the wet state but adhered upon drying.

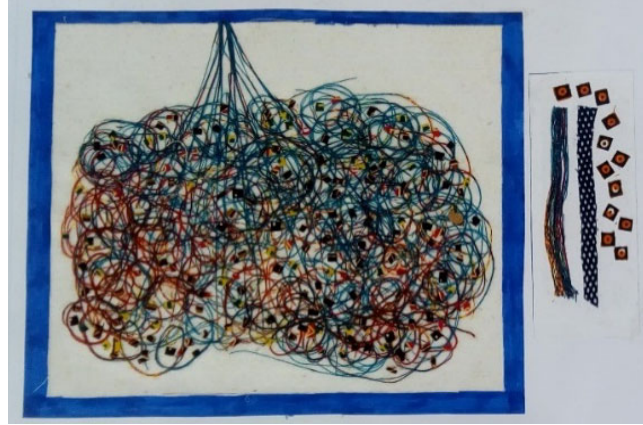

Fig. 9: Coiling of yarns in different directions

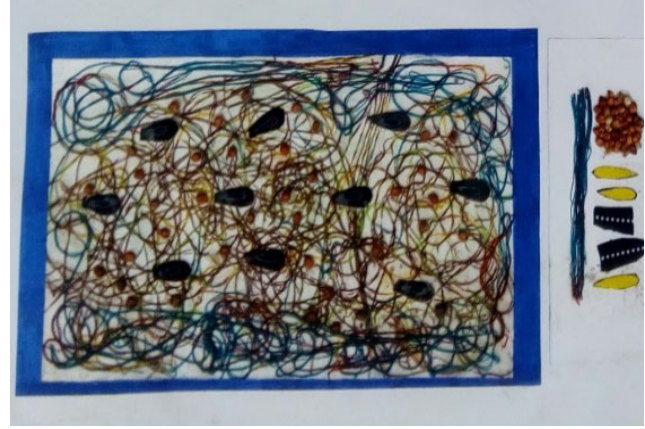

Fig.10: Yarn doodling on a fabric

(Source: Studio Work, 2019)

Yarns were removed from pieces of fabric which was used for the scribbling, varying the direction of the yarn, with an adhesive "fevicol SH". The scribbling process continued until a desirable technique was achieved known as yarn scribbling. A pattern was cut from a piece of fabric and stacked unto the scribbled yarn. Sorghum was stacked finally with an adhesive in the scribbled yarns for an effect to be created. 


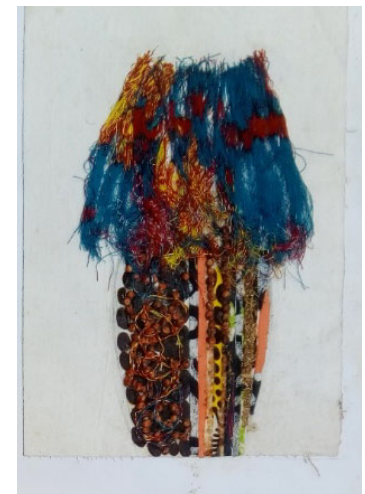

Fig. 11: Yarn Scribbling

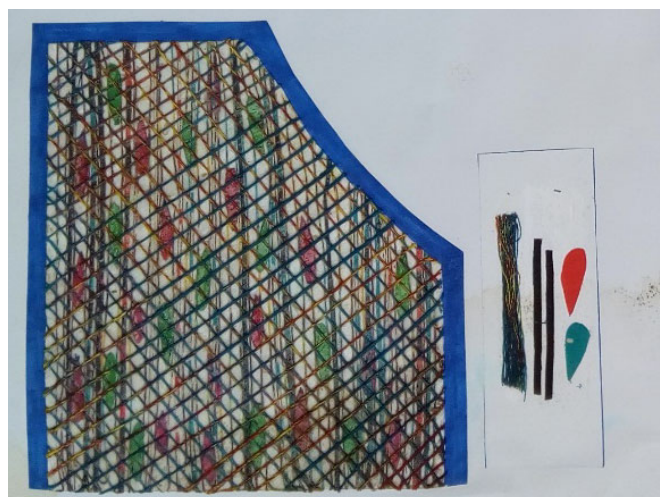

Fig. 12: Overlapping of twisted yarns

(Source: studio work, 2017)

The above technique represented in Fig. 12 shows how unraveled yarns were used in building the technique where two or three yarns were applied together. Stripes of fabrics were placed horizontally together with yarns using top bond as adhesive. In between the stripes of fabrics and yarns are oval designed patterns are placed randomly to create a design effect. Two or three yarns were plied and twisted; the yarns are placed in diagonal sections across the existing design created. This was repeated in parallel order creating an overlapping which looks like cross hatching.

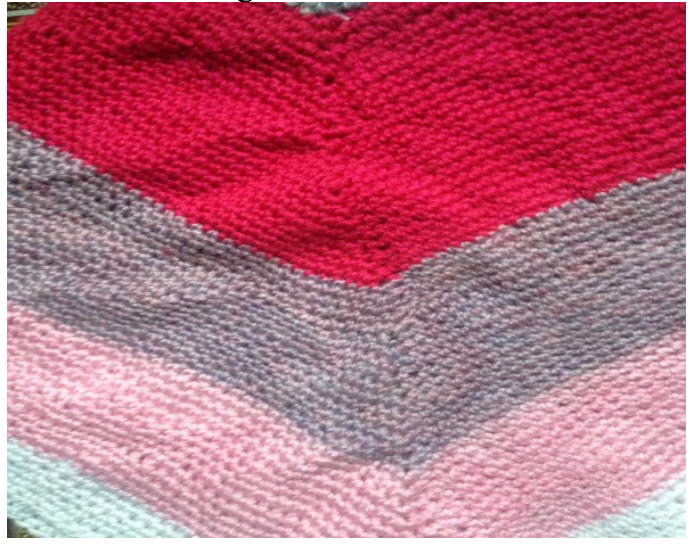

Fig. 13: Crocheting

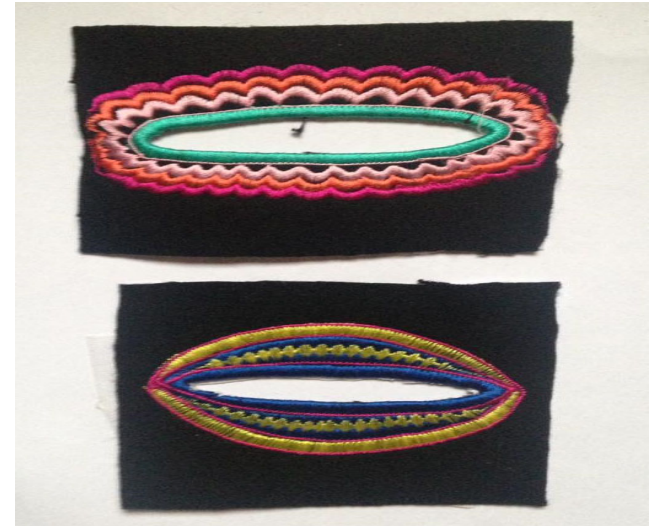

Fig. 14: Embroidery

(Source: Studio Work, 2017)

Crocheting was achieved by interlacing of thread using hand with the pin to weave a colourful fabric and embroidery machine was employed to produce the designs above (see Figures 13 and 14) which was used in the execution of the textile art piece. It was observed that two different adhesives (Fevicol SH and Super glue) were mixed together to increase the cohesion bond between the substrates. There was resistance in the process of gluing the twisted yarns to the substrate due to its coarser nature and so need some little pressure to adhere as it dries. Additionally, cotton-like materials have a strong bond with the adhesives more than the woolen blends, silk-like fabrics and so result in providing low elastic modules.

\section{Procedures and Practice Outcomes}

Essentially as stated early on, assemblage as a technique was exercised in putting together the gathered items in producing the art pieces. To carefully achieve the concept of mixed-media in textile art, different materials were exercised in cutting out the shapes of the drawn images.

\section{Textile Art Piece One - Ordeals in motherhood}

Fig. 15 measuring 4 feet by 3 feet represent a young woman resting in a pan holding her child on her lap and leaning against a construction block which indicate her resting mood after a hard days work. The struggle here is carrying a child on her lap along the street. The elements dominant here are colour, texture, space, line and unity and variety of materials are the major principle of design employed by the artist to create meaning and mood in his work. The face, the baby, leg and the arm were carved with wood. The blouse, the skirt and the fabric of the child was achieved by applique method using fabric pieces. The construction block against which the female potter (kayayo) was leaning and the pan in which she was resting is made of paper card finished with acrylic paint. The backgound of the art piece was achieved by laying a horizontal black thread (chrocheting thread) across the width of the art piece which suggest rest. 


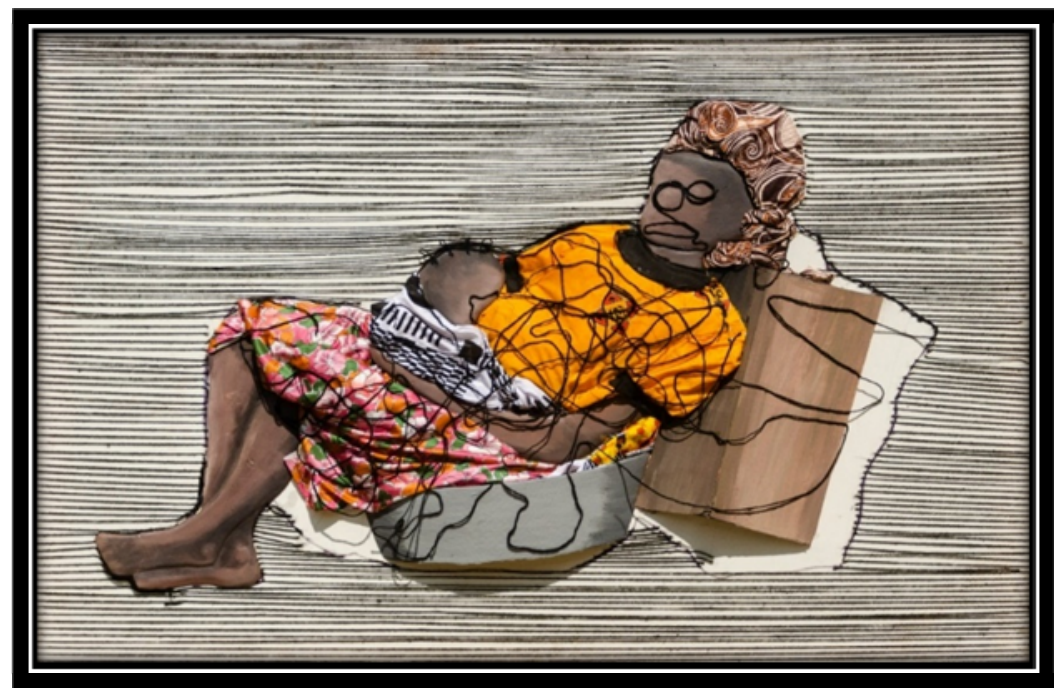

Fig. 15: Odeals in motherhood

(Source: Studio Work, 2019)

This textile piece titled Ordeals in motherhood explain the fact that the female potter is trying hard to single-handedly look after the child as well as carry out her dairly duties. Amidst all this she does not have a place to lay her head and so she rest by the roadside which poses a high risk. The fabric is characterised by fauvistic colour application, irregular and assymmetric use of design elements such as line, texture and shape/forms, symbolisms, conceptual consideration and contextual aesthetics. According to Supluteren (1990), artist may decide to use materials separately or can combine them if only the chosen materials are durable enough to fulfil its purpose. For example the work of Yinka Shonibare who used local prints on dummies. The art of mixed media mostly involves cubism artist where they combine different materials in the production of their works to create texture and mood in their works.

The doodling effect of the thread on the image was adopted by a continuous moving of the thread without a break to depict the entanglement of the female head potter who is struggling to make an ends meat and also somehow play the role of a mother. The black thread represent sad moment of the female head potter being bond by the web of a spider and trying to escape that bondage through carrying of loads on their head for a charge fee to cater for their family. The female head porter (kayayo) has to work hard and support her family because the so called bread winner cannot provide any bread for the family, so she is forced to support the family and at the same time be responsible for the up bringing of the child. She is faced with numerous battles in a foreign land and she must do whatever she can to preserve her womanhood; not only that, she must also be a good mother to her child. The irregularities of the lines (thread) at the background represent the differences in the lives of these female head potters (kayayie) with regards to their challenges. The hirizontal lines significant to attain rest, the hope glory for her in the future. Some lines are parallel and some converging which signifies some of them will be able to meet their dream whilst others will still be in the situation. There is no smooth road to success, one must be ready to face challenges in life. Once you are able to sail true, then there is light at the end of the tunnel. The work is suitable for wall hanging and can also be placed at any place of convenience as textile art. 


\section{Textile Art Piece Two - Journey of thousand miles}

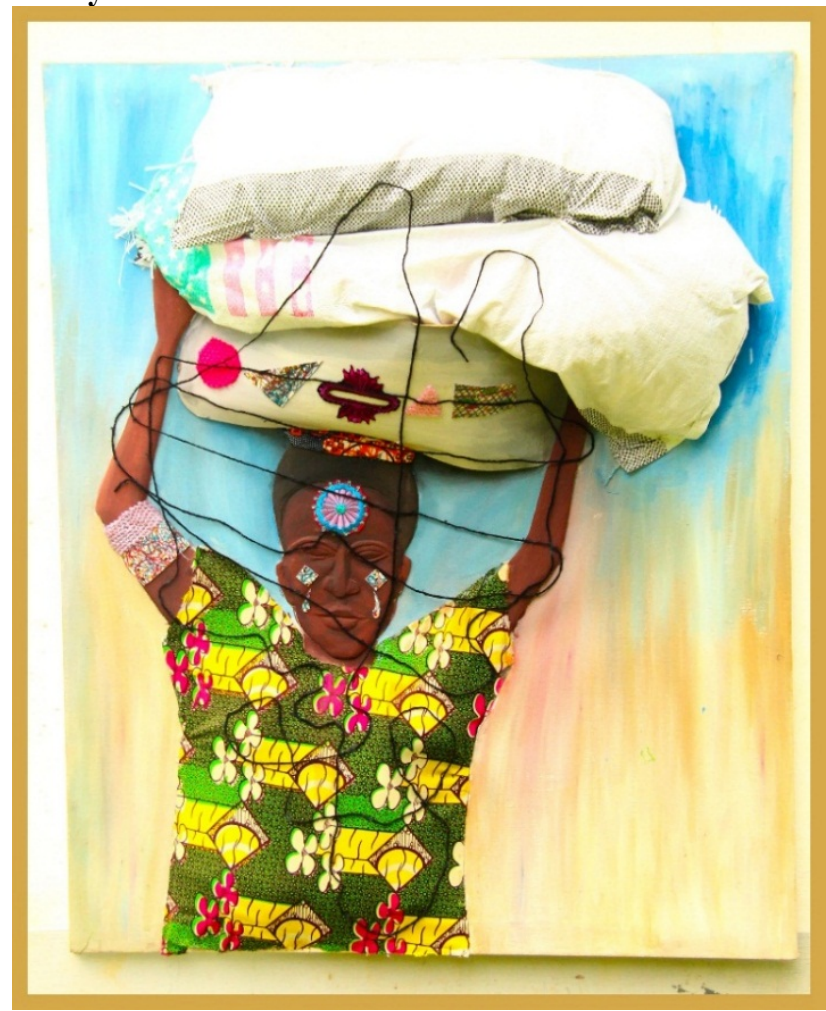

Fig. 16: Journey of thousand miles

(Source: Studio Work, 2019)

This textile art piece (see Fig. 16) titled journey of thousand miles measures 3.8 feet by 3 feet is the representation showing a female head porter carrying a load beyond her capability. The state of the kayayie poses a destiny bound by a distasteful journey that creates an ending repetition of an overburdened task to make a living. Even though kayayie may suffer with his weight to cover his journey in a short distance, but the anxiety and desperation to lift off the uneasy weight makes each step seem miles and miles apart. For a fact, he gets to his destination to lift off his load which he suffers much and takes no delight in the next task but to make a living or to survive, he cannot do away with the next task. The element dorminant here is colour, line, texture, space and unity and variety of materials are the major principle of design employed by the artist to create meaning and mood in his work. Fosu (1994) is of the view that, art works produced in Ghana is made of different materials and this works can mostly be found in Northern part of Ghana. He further stated that, the beauty of Northern art works influences the production of artistic works using mixed media techniques. The expression is made up of numerous techniques which are represented in geometric shapes such us circle, diamond-like shape, striangle, and rectangular shapes. The techniques employed are: Carving, modeling, applique, sewing, yarn doodling, crocheting, scribbling of yarn, plied yarn cross hatching, embroidery and painting. The doodling techniques on the expression signify their entanglement and working hard to come out of their ordeal. 


\section{Textile Art Piece Three - Strive for bread cramps}

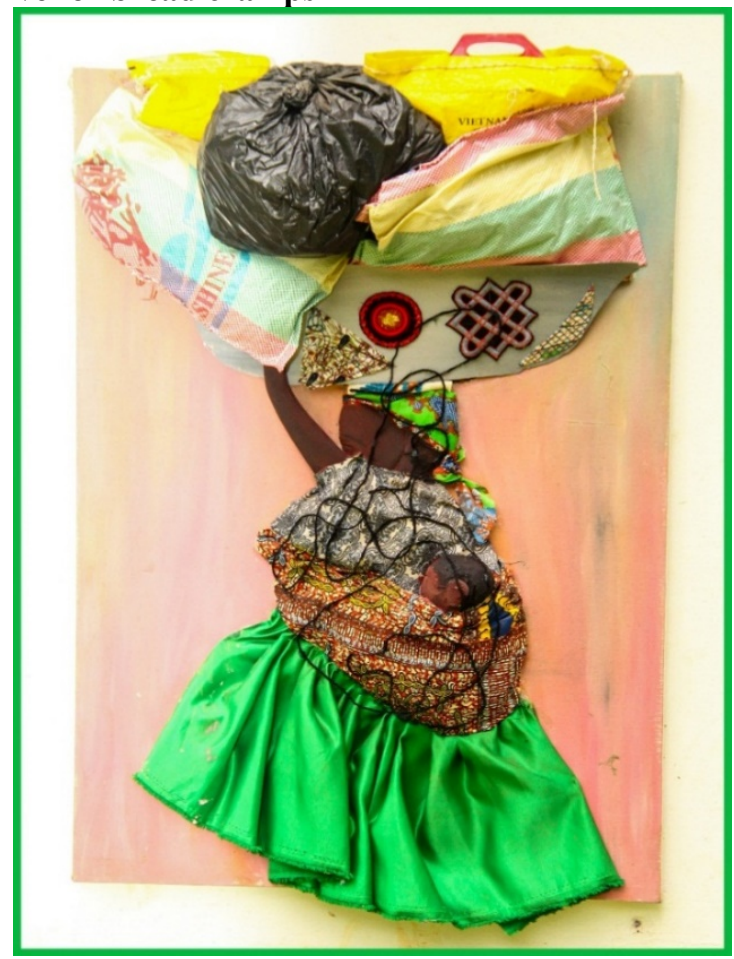

Fig. 17: Strive for bread cramps

(Source: Studio Work, 2019)

Bread cramps is not something of value to strive for but in this case, the effort the female head potter makes or put in her work brings a return of a very less value. The kayayie seeks to play the role of a mother as she carries her luggage on her head. The baby's hand and feet are bound in a cloth at her mother's back depicting lack of freedom of movement for the baby due to the mother's current situation. This clearly depicts the extent of her ordeal as she sought to meet her target for the day. Materials have been glued together by the help of super glue and fevicol SH glue. Polyethylene, paper card, fabric pieces, crocheting thread, and bridal satin coupled with techniques such as embroidery, yarn doodling, twisted plied yarns and major techniques carving, applique, modeling, sewing and painting. The doodling technique on the expression portrays them been caught in a web and their making frantic effort to escape those difficulties.

\section{Conclusion}

This practice-based study created textile art from mixed-media gathered from the environment. These art pieces illustrate the ordeals female head potters (kakayie) go through in their everyday activities in the streets or market places of Kumasi and Accra in Ghana. The involvement of young teenage girls into the kayayie business and their exposure to strenuous and hazardous condition is a social problem, particularly against efforts by government and non-governmental organizations to step up girl child education. Again, it brings into focus failures of government to bridge the gap between the northern and southern parts of Ghana. Evidently, extreme poverty has pushed many of these children and young women into the activity. However, the demeaning nature of the economic activity as regarded by most Ghanaians stems from the poor working conditions. Safety issues of carrying heavy loads on the head cannot be understated; the result of which is the frequent headaches, Fatigue and back aches reported by kayayei involved in the study. Aside the struggles of these female head porters, the various observations drawn from the expressions of kayayie drew more light to the researcher to produce selected samples on Kayayie expression into a complete mixed media textile art which could be used as wall hanging as well as mounted for exhibition for public view. Techniques such as applique, sewing, painting, carving and modelling were exercised in producing the assembled art works. In addition, materials such as crocheting threads, adhesives (Fevicol SH and Super glue), paper card, foam, waste papers, wood, fabric pieces, sandpaper and polish were combined to achieving a finished product.

\section{Recommendations}

Adhesives aids in bonding two substrates firmly together. It was revealed from the experiment that fevicol SH and super glue were ideal in producing permanent bonds and not fragile bonds between the items. In the light of this, to achieve total bond, artists and students should employ such adhesives in their creative process. The study 
recommends that practical lessons in tertiary institution should be designed to encourage students to utilize alternative materials within the environment to produce textile art.

\section{References}

Adiamah, N. E. (1995). Selected Approaches to Mixed Media Art. MA Thesis, p 5. Accessed 29 August, 2017 (12:33pm). From http://www.state.nj.us/dep/dshw/resource/njsrpm.

Adamson, G. (2007), Thinking Through Craft, Oxford: Berg. Retrieved July 2, 2017, from https://scholarworks.iu.edu/journals/index.php/mar/ article/download/107/186

Appiah-Ofori, D.G. (1991). Macramé Mixed Media for Interior Design. Unpublished MA Thesis, p 9. Accessed $22^{\text {nd }}$ October, 2017. from http://www.okstate.edu/ag/agedcm4h/academic/aged5980a/5980/newpage110.htm.

Appiah, I. J. (2013). Textile Art: Break in Tradition. Unpublished Seminar Presentation. Textiles Section, KNUST, Kumasi

Batik Guild (1999). The Art of Batik. Retrieved 10th may, 2018 from www.batikguild.com.

Barry, L. (2000). Textiles. Retrieved October 09, 2017, from http://www.wasteonline.org.uk/resources/Wasteguide/mn_wastetypes textiles.hml

Caulfield, K. (2009). Sources of textile waste in Australia. Retrieved September 07, 2017. From: http://www.ttna.com.au/TEXTILE\%20WASTE\%20PAPER\%20March\%20.

Dona, M. (1964). Collage and Found Art. New York: Art Horizons Inc. retrieved $3^{\text {rd }}$ November, 2017 (3:41pm). From http://spa.hust.edu.cn/2008/uploadfile/2009-9/20090916221539453

Fosu, K (1994). Traditional Art of Ghana. Dela Publications and Design Services, Kumasi. p 60 From: http://vscheiner.brunel.ac.uk/bitstream /2438/2040/1/JOS\%20.pdf

Graven, W. (1994). American Art History and Culture, New York: McGraw Hill Companies Inc. Accessed 23 $3^{\text {rd }}$ December, 2017 (10:56pm). from http://www.prem online.org/archive/17/doc/creed10e.

Marshall, C. (2010). A Research Design for Studio-Based Research in Art, Teaching Artist Journal, 8:2, 77-87, DOI: $10.1080 / 15411791003618597$.

Mirror, (Friday, November 17-23, 2017). Kayayie still urbanization Crisis. Pg. 8/28

Peter and Murray (1983). Dictionary of Art \& Artists. Penguin Book Ltd, England, p 274. From: http://www.marxists.org./reference/archive/murray/works

Russell, A. (2011). The fundamentals of printed textile design. London, UK: AVA Publishing. Assessed $13^{\text {th }}$ January, 2018 (2:13pm). From http://www.spikedonline. com/Articles/00000006DFD9.htm

Seymour, R. (2002). What is Design, Design Council's: Design in Business Week. Retrieved 13 November, 2017. From http://www.india-crafts.com/textile/textile-design.html

Supluteren, C (1990). The fine Art Series. How to use mixed media Materials. Newton Abbot Devon, p11. Assessed 24 ${ }^{\text {th }}$ February, 2018 (10:42pm). From http://www.p2pays.org/ref/41/40956

Terashima, A. (2009). Pattern Factory. New York, NY: Collins Design. Assessed 30 ${ }^{\text {th }}$ May 2017 (2:56pm). From http://www.p2pays.org/ref/41/40956.

Yeboah, T., Owusu, L., Arhin, A., \& Kumi, E. (2014). Fighting poverty from the street: Perspectives of some female informal sector workers on gendered poverty and livelihood portfolios in Southern Ghana. Journal of Economic and Social Studies, 5(1). doi:10.14706/JECOSS11511. ISSN 1986-8502. retrieved from http://msvuart.ca/index.php?menid=04/02\&mtyp=2\&article id=387 